\title{
Species diversity and composition, and above-ground carbon of mangrove vegetation in Jor Bay, East Lombok, Indonesia
}

\author{
ZULHALIFAH $^{1}$, ABDUL SYUKUR $^{1,2, \boldsymbol{\varphi}}$, DIDIK SANTOSO ${ }^{1,2}$, KARNAN $^{2}$ \\ ${ }^{1}$ Graduate Program of Science Education. Universitas Mataram. Jl. Majapahit No. 62, Mataram 83126, West Nusa Tenggara, Indonesia \\ ${ }^{2}$ Department of Science Education. Faculty of Teacher Training and Education, Universitas Mataram. Jl. Majapahit No. 62, Mataram 83126, West Nusa \\ Tenggara, Indonesia. Tel.: +62-370-623873, Fax.: +62-370-634918, "email: syukurbiologi@unram.ac.id
}

Manuscript received: 16 February 2021. Revision accepted: 28 March 2021.

\begin{abstract}
Zulhalifah, Syukur A, Santoso D, Karnan. 2021. Species diversity and composition, and above-ground carbon of mangrove vegetation in Jor Bay, East Lombok, Indonesia. Biodiversitas 22: 2066-2071. Mangroves play a very important role to mitigate global warming. This study aimed to assess the species diversity and composition as well as the above-ground biomass and carbon content of mangroves in Jor Bay (Teluk Jor), Lombok Island, Indonesia. A purposive sampling method was implemented using transects and square plots as data collection techniques. The data was analyzed to reveal the frequency, density, dominance, above-ground biomass, and carbon content. The results of this study found seven mangrove species, namely Avicennia marina, Ceriops tagal, Rhizophora apiculata, Rhizophora stylosa, Sonneratia alba, Sonneratia caseolaris, and Lumnitzera racemosa. In general, Sonneratia alba was the most important species in terms of frequency, density, and dominance followed by Rhizophora apiculata. In total, mangrove vegetation in Jor Bay stored 697.45 ton $\mathrm{C} / \mathrm{ha}$, or equivalent to carbon monoxide uptake of $2559.63 \mathrm{CO}^{2} / \mathrm{ha}$. In accordance with species composition, Sonneratia alba had the largest contribution to total carbon content with 453.76 tons C/ha), followed by Rhizophora apiculata with 74.47 tons $\mathrm{C} / \mathrm{ha}$. These findings suggest that mangrove vegetation in Jor Bay stored large amount of carbon in the form of above-ground biomass, implying the importance to preserve this area for carbon conservation.
\end{abstract}

Keywords: Conservation, content of carbon, mangrove species, mangroves

\section{INTRODUCTION}

Carbon emissions have been a major concern worldwide since their rapid increase in the atmosphere which triggers global warming (Florides et al., 2009; Hansen et al. 2013; Shakun et al. 2021). Global warming is the condition of warmer climate of the earth compared to the historical condition due to the accumulation of greenhouse gases, such as $\mathrm{CO}_{2}$ (around 50\%), chlorofluorocarbon (CFC, 25\%), methane gas (10\%), and other gases (Anderson et al. 2016; Kweku et al. 2017). Nonetheless, the impacts of global warming could be reduced through organic carbon sequestered from photosynthesis and stored in woody biomass, such as mangrove forest tree stands (Estrada et al. 2014; Santos et al. 2017; Virgulino-Júnior et al. 2020).

Mangrove forests are among ecosystems with the richest in carbon content globally (Alongi 2012), with most of the carbon stored underground (Kristensen et al. 2008; Mcleod et al. 2011). Several studies have presented the carbon cycle in mangrove forests and the primary production of synthesis, biomass, litter production, decomposition, carbon emissions, and other variables from them (Bouillon et al. 2008; Breithaupt et al. 2012). Mangroves can store more carbon than terrestrial forests (Alemaheyu et al. 2014; Banuwa et al. 2019; Iksan et al. 2019). Each mangrove species has a different capacity for storing carbon (Donato et al. 2011).
While mangrove forests have a crucial role in mitigating climate change, the existing management and utilization are not necessarily resembling the efforts to preserve their persistence (Iksan et al. 2019). For example, in Indonesia, the rate of degradation and loss of mangrove forests is high, almost $50-60 \%$, which is caused by anthropogenic activities, such as logging, settlements, mining, salt ponds, fisheries, and other industrial projects (Malik et al. 2015; Murdiyarso et al.2015; Ilman et al.2016; Malik et al. 2017). These problems have caused the management of mangroves for the conservation of coastal areas to become very complicated.

One parameter commonly used to assess the success in mangrove management and conservation is the diversity of fauna associated with mangrove species (Idrus et al. 2019a). An example from ecological aspect highlights the presence of mangroves that have vital function in the connectivity of the diversity of fish species associated with seagrass (Syukur et al. 2021). In some cases, the management and conservation of mangrove ecosystems would involve reforestation programs to ensure that the mangroves are in good condition and grow continuously, such as in Pasar Banggi, Rembang District, Indonesia (Saputro et al. 2019).

In other instances, the success of mangrove revegetation can be seen from social aspect through how local communities obtain livelihoods from the mangrove ecosystem (Idrus et al. 2019a). While some indicators have been explored to assess the sustainability of mangrove 
conservation as mentioned above, another indicator that can be used is carbon content in mangrove species.

Studies on carbon content in mangrove species have been rarely conducted, moreover in a lesser-known region such as in Lesser Sunda Islands, including Lombok, Indonesia. Thus, this study aimed to assess the species diversity and composition as well as the above-ground biomass and carbon content of mangroves in Jor Bay (Teluk Jor), Lombok Island. The results of this study can be a source of information for the management in the area, especially as an ecological monitoring tool to support mangrove conservation programs.

\section{MATERIALS AND METHODS}

\section{Study area and period}

The study was conducted in Jor Bay (Teluk Jor), East Lombok District, Lombok Island, Indonesia (Figure 1). Jor Bay is located in the southeastern part of Lombok Island. This research was conducted for five months, from January to May 2020. The study location has an area of 61.52 ha (Idrus et al. 2019b), which is a buffer zone of the Mandalika Special Economic Zone on the southern coast of Lombok Island.

\section{Data collection and analysis}

Data was collected using transect method. Five locations were selected to establish a line transect with length of $100 \mathrm{~m}$ perpendicular to the coastline (Figure 1). In each transect three sample plots (squares) were made so that a total of fifteen plots were made. Plot sizes differed for mangroves for tree, sapling, and seedling categories. Plot size $10 \times 10 \mathrm{~m}$ for trees (height $>1.5 \mathrm{~m}$ ), $5 \times 5 \mathrm{~m}$ for saplings (height $>1.5 \mathrm{~m}$ ), and $2 \times 2 \mathrm{~m}$ for seedlings (height $\leq 1.5 \mathrm{~m}$ ) (Figure 2) with $10 \mathrm{~m}$ spacing between squares. In each plot, all mangrove species were recorded and identified along with the number of trees, saplings, and seedlings. The circumference of the tree trunk was measured at $1.3 \mathrm{~m}$ from the ground. The data was then analyzed to calculate the frequency, density and area of cover (dominance). An analysis of carbon content was then carried out by calculating the volume and biomass.

$10 \mathrm{~m}$

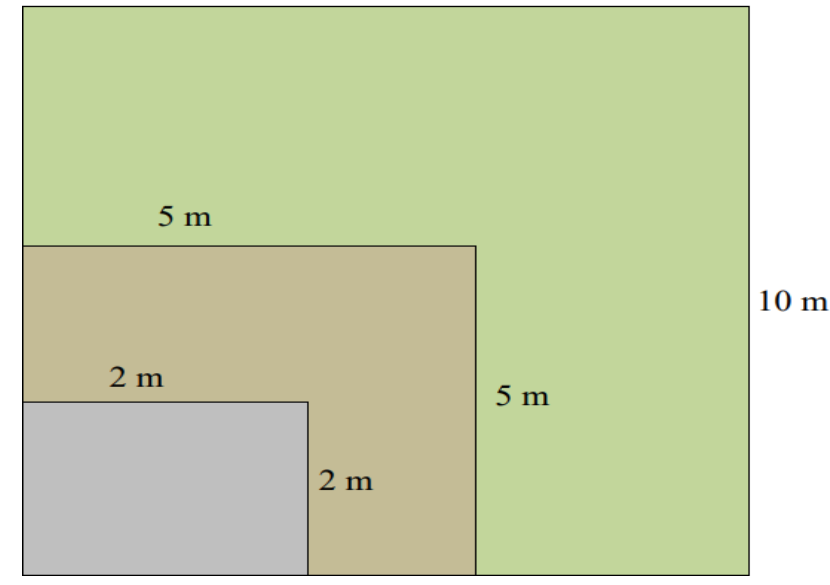

Figure 2. Mangrove plots

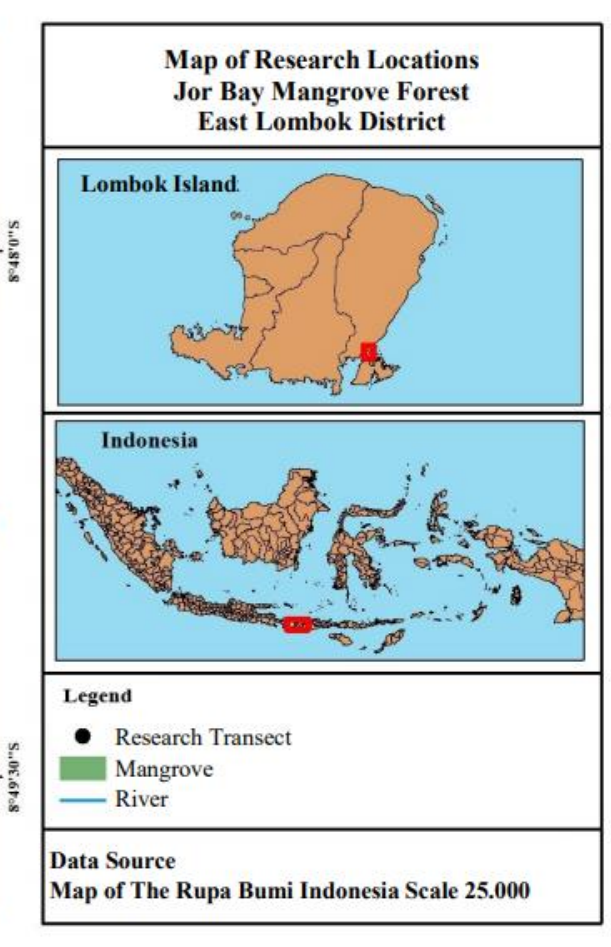

Figure 1. Map of the study sites in Jor Bay, Lombok Island, Indonesia which consisted of five transects 


\section{Frequency}

Frequency is the intensity of finding a species in a community or ecosystem. For the purposes of plant community analysis, the Relative Frequency of a species (FR-i) was used and calculated using the following formula (Alongi, 2012):

$$
F R-i=\frac{\text { Number of Plots Where a Species is Found }}{\text { Sum of All Sample Plots }}
$$

\section{Density}

Density is the number of individuals per unit area or unit volume. The density of the species can be calculated as $\mathrm{K}-\mathrm{i}$ and the relative density of each species to the total density can be calculated as KR-i. The formula for calculating Relative Density of a species is as follow:

$$
\mathrm{KR}-\mathrm{i}=\frac{\text { Species Density }}{\text { Density of All Species }} \times 100 \%
$$

\section{Coverage area}

The coverage area is the proportion between the area covered by plant species and the total habitat area. Relative species closure is the ratio between the area of type i cover and the total area covered for all species. The formula is as follows:

$$
\mathrm{CR}-\mathrm{i}=\frac{\text { Species Closure }}{\text { Cover of All Species }} \times 100 \%
$$

The potential carbon content of mangrove species was determined using non-destructive sampling method prescribed by the IPCC (IPCC 2003). The volume of mangrove was first calculated to produce biomass value, which was then converted into carbon content. The volume was calculated using the following formula:

$$
\begin{aligned}
& \mathrm{V}=1 / 4 . \Pi \cdot \mathrm{d}^{2} . \mathrm{t} . \mathrm{f} \\
& \text { Where: } \\
& \mathrm{V} \quad: \text { volume of trees }\left(\mathrm{m}^{3}\right) \\
& \Pi \quad: \text { constant }(3,14) \\
& \mathrm{d} \quad: \text { diameter at breast height } \\
& \mathrm{t} \quad: \text { total height }(\mathrm{m}) \\
& \mathrm{f} \quad: \text { tree shape number }(0,6)
\end{aligned}
$$

Then the biomass was calculated as follow:
Biomass $=\mathrm{V} x$ wood density

Where: the wood density of Rhizophora $=0.92$; Bruguiera $=0.91 ;$ Avicennia $=0.74 ;$ Sonneratia dan Xylocarpus $=0.74 ;$ Ceriops $=0.85 ;$ Lumnitzera $=0.88$; (Alongi, 2012).

Then the carbon content was calculated following IPCC (2003):

Carbon content $=$ biomass $\times 50 \%$

The calculation of carbon dioxide $\left(\mathrm{CO}_{2}\right)$ absorption used the formula:

$\mathrm{CO}_{2}=\mathrm{Mr} . \mathrm{CO} / \mathrm{Ar} . \mathrm{C} \mathrm{x}$ carbon content

Where:

$\mathrm{CO}_{2}$ : Carbondioxia uptake

$\mathrm{Mr}$ : Relative molecule

$\mathrm{Ar}$ : Relative atom

\section{RESULTS AND DISCUSSION}

\section{Composition of mangrove species}

The results of the study found seven natural mangrove species apart from the mangrove vegetation species, namely Avicennia marina, Ceriops tagal, Lumnitzera racemosa, Rhizophora apiculata, Rhizophora stylosa, Sonneratia alba and Sonneratia caseolaris (Table 1). The most dominant mangrove species was Sonneratia alba, as this species prefers muddy habitats and areas of high salinity to achieve optimal growth (Idrus et al. 2019a). Lumnitzera racemosa less dominated since this species has low adaptability in the location. Hence, it can be assumed that environmental conditions have a direct effect on the growth and development of mangrove vegetation. Among all transects, Transect III had the highest abundance of mangrove species which is due to the location having a muddy substrate.

Table 1. The composition and abundance of mangrove species in Jor Bay, Lombok, Indonesia

\begin{tabular}{lcccccc}
\hline Species & Transect I & Transect II & Transect III & Transect IV & Transect V & Total individuals \\
\hline Avicennia marina & - & 10 & 10 & - & 4 & 17 \\
Ceriops tagal & - & - & 17 & - & - & 34 \\
Lumnitzera racemosa & - & - & 10 & - & 11 & 10 \\
Rhizophora apiculata & 10 & 95 & - & - & 22 & 118 \\
Rhizophora stylosa & 22 & - & 116 & 45 & - & 232 \\
Sonneratia alba & 39 & - & 22 & - & 22 \\
Sonneratia caseolaris & - & - & & & \\
\hline
\end{tabular}




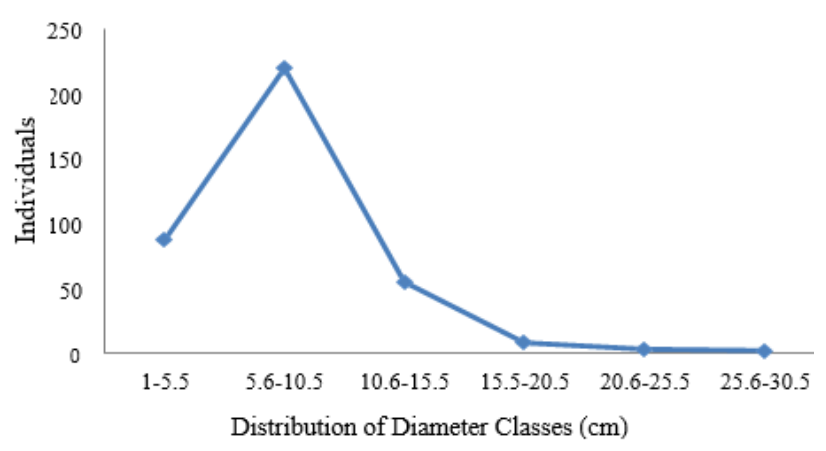

Figure 3. Number of mangrove individuals across diameter classes

Table 2. Relative Frequency (FR), Relative Density (KR) and Relative Dominance (DR) of trees of mangrove species in Jor Bay, Lombok, Indonesia

\begin{tabular}{llll}
\hline Species & FR $(\%)$ & KR $(\boldsymbol{\%})$ & DR $(\%)$ \\
\hline Avicennia marina & 5.26 & 2.38 & 3.31 \\
Ceriops tagal & 5.26 & 2.38 & 1.90 \\
Rhizophora apiculata & 10.53 & 5.95 & 1.50 \\
Rhizophora stylosa & 5.26 & 2.38 & 1.86 \\
Sonneratia alba & 68.42 & 83.33 & 87.51 \\
Sonneratia caseolaris & 5.26 & 3.57 & 3.93 \\
Total & 100 & 100 & 100 \\
\hline
\end{tabular}

Table 3. Relative Frequency (FR), Relative Density (KR) and Relative Dominance (DR) of saplings of mangrove species in Jor Bay, Lombok, Indonesia

\begin{tabular}{llll}
\hline Species & FR $(\boldsymbol{\%})$ & $\mathbf{K R}(\boldsymbol{\%})$ & DR $(\boldsymbol{\%})$ \\
\hline Avicennia marina & 6.90 & 4.20 & 7.16 \\
Ceriops tagal & 6.90 & 8.74 & 5.41 \\
Lumnitzera racemosa & 3.45 & 3.50 & 1.02 \\
Rhizophora apiculata & 27.59 & 26.57 & 25.76 \\
Rhizophora stylosa & 10.35 & 3.50 & 3.56 \\
Sonneratia alba & 41.38 & 46.85 & 48.34 \\
Sonneratia caseolaris & 3.45 & 6.64 & 8.76 \\
Total & 100 & 100 & 100 \\
\hline
\end{tabular}

Table 4. Relative Frequency (FR), Relative Density (KR), and Relative Dominance (DR) of seedlings of mangrove species in Jor Bay, Lombok, Indonesia

\begin{tabular}{lll}
\hline Species & FR $(\boldsymbol{\%})$ & KR $(\boldsymbol{\%})$ \\
\hline Avicennia marina & 5.56 & 10.00 \\
Ceriops tagal & 5.56 & 2.00 \\
Rhizophora apiculata & 27.78 & 37.00 \\
Rhizophora stylosa & 22.22 & 23.00 \\
Sonneratia alba & 38.89 & 28.00 \\
Total & 100 & 100 \\
\hline
\end{tabular}

\section{Diameter distribution}

The density of mangroves varied across diameter classes (Figure 2). Mangrove with diameter class of 5.6$10.5 \mathrm{~cm}$ had the highest density with 220 individuals, followed by the class of $1-5.5 \mathrm{~cm}$ with 80 individuals. While classes of $20.6-25.5 \mathrm{~cm}$, and $25.6-30.5 \mathrm{~cm}$ had only three individuals. The mangrove density graph forms an inverted but imperfect $\mathrm{J}$ curve. The high and low number of individuals at specific diameter classes illustrates that the forest experienced structural changes. These changes affect the sustainability of the subsequent regeneration of forest stands. The 5.6-10.5 cm diameter class was mostly found in Jor Bay due to tree felling activities where people generally used mangrove wood excessively, or this can be due to uprooted by the wind (Din et al. 2008; Osti et al. 2009). Other destructive activities included the conversion of mangrove land into ponds and illegal logging in the area.

Other studies in the Regional Marine Protected Area in Gili Sulat, East Lombok showed that mangrove vegetation structure resembles an inverted $\mathbf{J}$ curve where the seedling had the highest number of individuals while the trees had the lowest (Setiawan and Mursidin 2018). Similarly, mangrove stands on Tanakeke Island, South Sulawesi showed that the number of trees decreases with the curve resembled an inverted $\mathrm{J}$; these characteristics indicate that the forest is balanced (Suwardi et al. 2013). The availability of stands in community-managed forests will form a very high inverted $\mathbf{J}$ curve to guarantee the future (Ontorael et al. 2012).

The relative frequency, relative density, and relative dominance of tree categories for each mangrove species are different (Table 2). Sonneratia alba had the highest relative frequency $(68.42 \%)$, followed by the Rhizophora apiculata $(10.53 \%)$, while the four other types were the lowest $(5.26 \%)$. Similarly, the highest relative density value was seen in Sonneratia alba (83.33\%), followed by the Rhizophora apiculata (5.95\%), and the lowest was three other species (2.38\%). Again, the Sonneratia alba had the highest relative dominance of tree $(87.51 \%)$, followed by Sonneratia caseolaris $(3.93 \%)$, and the lowest was the Rhizophora apiculata (1.50\%) (Table 2).

The highest value of relative frequency in the sapling category was Sonneratia alba (41.38\%), followed by Rhizophora apiculata (27.59\%), and the lowest were two other species $(3.45 \%)$ (Table 3). Similarly, the highest relative density was Sonneratia alba $(46.85 \%)$, followed by the Rhizophora apiculata $(26.57 \%)$, and the lowest were other two species (3.50\%). Again, Sonneratia alba had the highest value of relative dominance (48.34\%), and Rhizophora apiculata $(25,76 \%)$ ranked second, and Lumnitzera racemosa (1.02\%) was the lowest.

The high relative frequency and relative density of Sonneratia alba at tree and sapling levels are due to the higher adaptability to environmental factors which support the optimal growth of this species compared to other species. The highest relative dominance of this species is also caused by their ability to obtain more nutrients to ensure that the stem volume is large enough and the canopy is wide, resulting in its dominance over other types; additionally, it also prefers muddy substrates and tolerates high salt level (Ardiansyah et al. 2012; Nurdin et al. 2015; Urrego et al. 2014 ). 
Table 5. Volume, biomass, carbon content and $\mathrm{CO}_{2}$ uptake of mangrove vegetation in Jor Bay, Lombok, Indonesia

\begin{tabular}{lllll}
\hline Species & $\begin{array}{l}\text { Volume } \\
\left(\mathbf{m}^{\mathbf{3}} / \mathbf{h a}\right)\end{array}$ & $\begin{array}{l}\text { Biomass } \\
\text { (ton/ha) }\end{array}$ & $\begin{array}{l}\text { Carbon content } \\
\text { (ton C/ha) }\end{array}$ & $\begin{array}{l}\text { Absorption } \\
\left.\mathbf{C O}_{2} \text { (ton } \mathbf{C O}_{2} / \mathbf{h a}\right)\end{array}$ \\
\hline Avicennia marina & 2.45 & 36.72 & 18.36 & 67.38 \\
Ceriops tagal & 5.64 & 93.58 & 46.79 & 171.72 \\
Lumnitzera racemosa & 0.68 & 15.99 & 8.00 & 29.35 \\
Rhizophora apiculata & 7.52 & 148.92 & 74.47 & 273.30 \\
Rhizophora stylosa & 2.75 & 58.80 & 29.40 & 107.90 \\
Sonneratia alba & 66.49 & 907.52 & 453.76 & 1665.30 \\
Sonneratia caseolaris & 7.51 & 127.26 & 66.67 & 244.68 \\
Total & 93.04 & 1388.79 & 697.45 & 2559.63 \\
\hline
\end{tabular}

At sapling level, Sonneratia alba had the highest relative frequency $(38.89 \%)$, followed by Rhizophora apiculata (27.78\%) (Table 4). However, the highest relative density was Rhizophora apiculata (37\%), while Sonneratia alba ranked second. The highest relative density of the seedling category of Sonneratia alba is likely due to environmental factors that support the distribution of the seed compared to others. On the other hand, the highest relative frequency of Rhizophora apiculata at seedling category is because they can survive better in the environment during the juvenile stage than other species (Abino et al. 2014; Mitra et al. 2011 ).

\section{Biomass and carbon content}

The results of the analysis of volume, biomass, carbon content and carbon dioxide uptake are presented in Table 5. Sonneratia alba had the highest volume $\left(66.49 \mathrm{~m}^{3} / \mathrm{ha}\right)$ and Lumnitzera racemosa was the lowest (0.68 $\left.\mathrm{m}^{3} / \mathrm{ha}\right)$. Similarly, Sonneratia alba had the highest biomass value (907.52 $\left.\mathrm{m}^{3} / \mathrm{ha}\right)$, followed by Rhizophora apiculata (148.92 $\mathrm{m}^{3} / \mathrm{ha}$ ), and Lumnitzera racemosa being the lowest (15.99 $\mathrm{m}^{3} / \mathrm{ha}$ ). Sonneratia alba had the highest biomass (907.52 ton/ha) and carbon content due to its large trunk diameter and tree height. So that the greater the tree biomass, the greater the carbon absorbed. Thus, the total carbon content in aboveground vegetation in Teluk Jor is 697.45 ton $\mathrm{C} / \mathrm{ha}$ (equivalent to $2559.63 \mathrm{CO}_{2} / \mathrm{ha}$ ).

Biomass and carbon content in Teluk Jor is higher than those in Bahowo, Bunaken District with biomass of 433.69 ton/ha (equivalent to 748.07 ton of $\mathrm{CO}_{2} / \mathrm{ha}$ ) (Bachmid et al. 2018) and in Kubu Raya, West Kalimantan with biomass of 438.79 ton/ha (805.68 ton of $\mathrm{CO}_{2} /$ ha) (Prakoso et al. 2017).

Sonneratia alba had the highest tree density value than other trees and, thus, had the highest potential carbon stock. The higher the mangrove density, the greater the carbon content, where the stand density, stand composition and structure, and the quality of the mangrove growth sites affect the increase in biomass and carbon content of mangrove trees. Mangroves' ability to store carbon can reduce the rise in carbon emissions in nature (Alongi, 2020; Dinilhuda et al. 2018; Turner et al.2009; ). Mangroves per hectare can store four times as much carbon as other tropical forests worldwide. The mangrove vegetation in Teluk Jor can absorb carbon dioxide of $2559.63 \mathrm{CO}_{2} / \mathrm{ha}$, equivalent to the carbon dioxide emissions produced by the transportation of 241.46 ton $\mathrm{CO}_{2} /$ ha (Iqbal et al. 2017).
Mangrove forests can mitigate climate change by absorbing $\mathrm{CO}_{2}$ from the atmosphere and oceans at a much higher rate than terrestrial forests (Mcleod et al. 2011). Therefore, mangrove forests are one of the natural resources that must be preserved to reduce the impact of climate change.

In conclusion, mangrove forest resources have made important contributions to the environment. One of them is as a carbon sink. The mangroves in Jor Bay consisted of seven species (Sonneratia alba, Sonneratia caseolaris, Rhizophora stylosa, Rhizophora apiculata, Ceriops tagal, Avicennia marina, and Lumnitzera racemosa). Sonneratia alba was the most significant species in the studied area, followed by the Rhizophora apiculata. The analysis of biomass and carbon content suggests that the mangrove vegetation in Jor Bay has potential capacity in absorbing carbon dioxide.

\section{ACKNOWLEDGEMENTS}

The authors thank the Rector of Mataram University, Indonesia who helped provide laboratory facilities and research funding through the PNBP Mataram University for the fiscal year of 2020. Z, AS, DS, and K conducted all experiments, participated in data analysis and wrote the manuscript.

\section{REFERENCES}

Abino AC, Castillo JAA, Lee YJ. 2014. Assessment of species diversity, biomass and carbon sequestration potential of a natural mangrove stand in Samar, the Philippines. For Sci Technol 10 (1): 2-8. DOI: 10.1080/21580103.2013.814593.

Alemaheyu F, Richard O, James MK, Wasonga O. 2014. Assessment of mangroves covers change and biomass in Mide Creek, Kenya. J For 4 (4): 398-413. DOI: 10.4236/ojf.2014.44045.

Alongi DM. 2012. Carbon sequestration in mangrove forests. Carbon Manag 3 (3): 313-322. DOI: 10.4155/cmt.12.20.

Alongi DM. 2020. Global significance of mangrove blue carbon in climate change mitigation. Science 2 (3): 67. DOI: 10.3390/sci2030067

Anderson TR, Hawkins E, Jones PD. 2016. $\mathrm{CO}_{2}$, the greenhouse effect and global warming: from the pioneering work of Arrhenius and Callendar to today's Earth System Models. Endeavour 40 (3): 178187. DOI: 10.1016/j.endeavour.2016.07.002

Bachmid F, Sondak C, Kusen J. 2018. Estimasi penyerapan karbon hutan mangrove bahowo Kelurahan Tongkaina Kecamatan Bunaken. Jurnal Pesisir dan Laut Tropis 6 (1): 8-13. DOI: 10.35800/jplt.6.1.2018.19463. [Indonesian]

Banuwa IS, Utomo M, Yusnaini S, Riniarti M, Sanjaya P, Suroso E, Hidayat, W. 2019. Estimation of the above-and below-ground carbon 
stocks in University of Lampung, Indonesia. Biodiversitas 20 (3): 676-681. DOI: 10.13057/biodiv/d200309

Bouillon S, Borges AV, Castañeda-Moya E, Diele K, Dittmar T, Duke NC, Kristensen E, Lee SY, Marchand C, Middelburg JJ, RiveraMonroy VH, Smith III TJ, Twilley RR. 2008. Mangrove production and carbon sinks: A revision of global budget estimates. J Glob Biogeochem 22 (2): 1-12. DOI: 10.1029/2007GB003052.

Breithaupt JL, Smoak JM, Smith TJ, Sanders III CJ, Hoare A. 2012 Organic carbon burial rates in mangrove sediments: Strengthening the global budget. Glob Biogeochem Cycle 26 (3): GB3011, DOI: 10.1029/2012GB004375

Din N, Saenger P, Jules PR, Siegfried DD, Basco F. 2008. Logging activities in mangrove forests: A case study of Douala, Cameroon. Afr J Environ Sci Technol 2 (2): 22-030.

Dinilhuda A, Akbar AA, Jumiati J. 2018. Peran ekosistem mangrove bagi mitigasi pemanasan global. Jurnal Teknik Sipil 18 (2): 1-9. DOI: 10.26418/jtsft.v18i2.31233. [Indonesian]

Donato DC, Kauffman JB, Murdiyarso,D, Kurnianto S, Stidham M, Kanninen M. 2011. Mangroves among the most carbon-rich forests in the tropics. Nature Geosci 4 (5): 293-297. DOI: 10.1038/NGEO1123

Estrada GCD, Soares MLG, Santos DMC, Fernandez V, Almeida PMM, de Medeiros Estevam MR, Machado MRO. 2014. Allometric models for aboveground biomass estimation of the mangrove Avicennia schaueriana. Hydrobiologia 734 (1): 171-185. DOI: 10.1007/s10750014-1878-5.

Florides G A, Christodoulides P. 2009. Global warming and carbon dioxide through sciences. Environ Intl 35 (2): 390-401.

Hansen J, Kharecha P, Sato M, Masson-Delmotte V, Ackerman F, Beerling DJ, Zachos JC. 2013. Assessing "dangerous climate change": Required reduction of carbon emissions to protect young people, future generations and nature. PloS One 8 (12): e0081648. DOI: 10.1371 /journal.pone.0081648

Idrus AA, Syukur A, Zulkifli L. 2019. The diversity of fauna in mangrove community: Success replanting of mangroves species in south coastal East Lombok, Indonesia. J Phys: Conf Ser 1402 (3): 033042. DOI: 10.1088/1742-6596/1402/3/033042.

Idrus AA, Syukur A, Zulkifli L. 2019b. The livelihoods of local communities: Evidence success of mangrove conservation on the coast of East Lombok Indonesia. AIP Conf Proc 2199: 050010. DOI: $10.1063 / 1.5141308$.

Iksan M, Al Zarliani WOD, La Nare S, Baena F. 2019. Biomass and carbon uptake of mangrove forests Pohorua Village, Muna Regency. J Appl Biol 3 (2): 57-64.

Ilman M, Dargusch P, Dart P .2016. A historical analysis of the drivers of loss and degradation of Indonesia's mangroves', Land Use Pol 54 448-459. DOI: 10.1016/j.landusepol.2016.03.010

Intergovernmental Panel on Climate Change. 2003. IPPC Guidelines for Nation Greenhouse Inventories: Reference Manual IPCC. IGES, Japan.

Iqbal M, Sasmita A, Andrio D. 2017. Prediksi emisi karbon dioksida dari kegiatan transportasi di Kecamatan Bukit Raya Kota Pekanbaru. Jurnal Online Mahasiswa Fakultas Teknik Universitas Riau 4 (2): 1-3. [Indonesian]

Kristensen E. Bouillon S. Dittmar T, Marchand C. 2008. Organic carbon dynamics in mangrove ecosystems: A review. Aquat Bot 89 (2): 201219. DOI: 10.1016/j.aquabot.2007.12.005

Kweku DW, Bismark O, Maxwell A, Desmond KA, Danso KB, OtiMensah EA, Adormaa BB. 2017. Greenhouse effect: greenhouse gases and their impact on global warming. J Sci Res Rep 17 (6): 39630. DOI: $10.9734 / J S R R / 2017 / 39630$

Malik A, Fensholt R, Mertz O. 2015. Mangrove exploitation effects on biodiversity and ecosystem services. Biodiv Conserv 24 (14): 35433557.

Malik A, Mertz O, Fensholt R. 2017. Mangrove forest decline: consequences for livelihoods and environment in South Sulawesi.
Reg Environ Change 17 (1): 157-169. DOI 10.1007/s10113-0160989-0.

Mcleod E, Chmura GL, Bouillon S, Salm R, Björk M, Duarte CM, Silliman BR. 2011. A blueprint for blue carbon: Toward an improved understanding of the role of vegetated coastal habitats in sequestering $\mathrm{CO}_{2}$. Front Ecol Environ 9 (10): 552-560. DOI: 10.1890/110004.

Mitra A, Sengupta K, Banerjee K. 2011. Standing biomass and carbon storage of above-ground structures in dominant mangrove trees in the Sundarbans. For Ecol Manag 261 (7): 1325-1335. doi:10.1016/j.foreco.2011.01.012.

Murdiyarso D, Purbopuspito J, Kauffman JB, Warren MW, Sasmito SD, Donato DC, Manuri S, Krisnawati H, Taberima S, Kurnianto S. 2015. The potential of Indonesian mangrove forests for global climate hange mitigation. Nature Clim Ch 5 (12): 1089-1092.

Nurdin N, Akbar M, Patittingi F. 2015. Dynamic of mangrove cover change with anthropogenic factors on small island, Spermonde Archipelago. Proc. SPIE 9638, Remote Sensing of the Ocean, Sea Ice, Coastal Waters, and Large Water RegionsIn, Vol. 9638: 96380T. DOI: $10.1117 / 12.2194645$

Ontorael R, Wantasen AS, Rondonuwu AB. 2012. Kondisi ekologi dan pemanfaatan sumberdaya mangrove di Desa Tarohan Selatan Kecamatan Beo Selatan Kabupaten Kepulauan Talaud. Jurnal Ilmiah PLATAX 1 (1): 07-11. DOI: 10.35800/jip.1.1.2012.492. [Indonesian]

Osti R, Tanaka S, Tokioka T. 2009. The importance of mangrove forest in tsunami disaster mitigation. J Disasters 33 (2): 203-213. DOI: 10.1111/j.1467-7717.2008.01070.x.

Prakoso TB, Afiati N, Suprapto D. 2017. Biomassa kandungan karbon dan serapan $\mathrm{CO}_{2}$ pada tegakan mangrove di Kawasan Konservasi Mangrove Bedoo, Demak. J Maquares 6 (2): 156-163. DOI: 10.14710/marj.v6i2.19824. [Indonesian]

Santos D, Estrada GC, Fernandez V, Estevam MR, Souza BT, Soares ML. 2017. First assessment of carbon stock in the belowground biomass of Brazilian mangroves. J Anal Acad Bras Ciên 89 (3): 1579-1589. DOI: 10.1590/0001-3765201720160496.

Saputro DA, Purwanti F, Rudiyanti S. 2019. Mangrove tourism conditions in Pasar Banggi Village, Rembang Regency. J Maquares 8 (3): 221225. DOI: $10.14710 /$ marj.v8i3.24259.

Setiawan H, Mursidin. 2018. Karakteristik ekologi dan kesehatan hutan mangrove di Pulau Tanakeke Sulawesi Selatan. Jurnal Penelitian $\begin{array}{lllll}\text { Kehutanan Wallacea } 7 & \text { (1): 47-58. DOI: }\end{array}$ 10.18330/jwallacea.2018.vol7iss1pp47-58. [Indonesian]

Shakun JD, Clark PU, He F, Marcott SA, Mix, A C, Liu Z, Bard E. 2012. Global warming preceded by increasing carbon dioxide concentrations during the last deglaciation. Nature 484 (7392): 49-54. DOI: $10.1038 /$ nature10915.

Suwardi AB. 2013. Komposisi jenis dan cadangan karbon di hutan tropis dataran rendah Ulu Gandut Sumatera Barat. Jurnal Biologi 12 (2): 168-176. [Indonesian]

Syukur A, Idrus AA, Zulkifli L. 2021. Seagrass-associated fish species' richness: Evidence to support conservation along the south coast of Lombok Island, Indonesia. Biodiversitas 22 (2): 988-998. DOI: $10.13057 /$ biodiv/d220255.

Turner W R, Oppenheimer M, Wilcove DS. 2009. A force to fight global warming. Nature 462: 278-279. DOI: 10.1038/462278a.

Urrego LE, Molina EC, Suárez JA. 2014. Environmental and anthropogenic influences on the distribution, structure, and floristic composition of mangrove forests of the Gulf of Urabá (Colombian Caribbean). Aquat Bot 114: 42-49. DOI: 10.1016/j.aquabot.2013.12.006

Virgulino-Júnior PCC, Carneiro DN, Nascimento Jr WR, Cougo MF, Fernandes MEB. 2020. Biomass and carbon estimation for scrub mangrove forests and examination of their allometric associated $\begin{array}{llllll}\text { uncertainties. PloS One } 15 & \text { (3): e230008. DOI: }\end{array}$ 10.1371/journal.pone.0230008. 